\title{
United States v. Flores-Lopez: Protecting Privacy Rights in Cell Phone Searches Incident to Arrest*
}

\section{INTRODUCTION}

The Founders carefully drafted the Fourth Amendment to provide protection for "persons, houses, papers, and effects," purposefully shielding Americans from certain government intrusions. This protection of our papers and documents, or "freedom of conscience,", was of the utmost importance to the Founders, as government intrusions were a pressing issue in the late 1700s. Pre-Constitution Americans' fear of an overly intrusive government was exemplified in a pamphlet widely circulated throughout the colonies: ${ }^{3}$

What then, can be more excruciating torture, than to have [government agents] ... amuse themselves with the perusal of all private letters, memorandums, secrets and intrigues....

$\ldots$... [W]ould any gentleman in this kingdom rest one minute at ease in his bed, if he thought, that ... every secret of his family [was] made subject to the inspection of [the government]?

Recent advances in cellular phone technology have forced courts to reconsider the Fourth Amendment's range of protection. This Note discusses the particular situation involving a police officer's search of an arrestee's cell phone.

* Kevin Wempe. J.D. candidate 2014, University of Kansas School of Law, B.S. 2011, Emporia State University. I would like to thank Dean Melanie Wilson for providing her valuable knowledge and feedback in developing this Note. Thanks also to the The University of Kansas Law Review board and staff members for helping craft this Note from the author's initial ramblings and nonsense. Finally, an emphatic thank you to my family for their boundless support, which has always exceeded the amount deserved by a humbling margin.

1. U.S. CONST. amend. IV.

2. United States v. Seljan, 547 F.3d 993, 1014 (9th Cir. 2008) (Kozinski, C.J., dissenting).

3. Roger Roots, The Originalist Case for the Fourth Amendment Exclusionary Rule, 45 Gonz. L. REV. 1, 42 (2010).

4. Father of Candor, A Letter Concerning Libels, Warrants, and the Seizure of PAPERs; With A VIEW TO SOME LATE PROCEedings AND THE DEFENCE OF THEM BY THE MAJORITY 44 (London, $2 \mathrm{~d}$ ed. 1765), available at http://books.google.com/books?id=111nAAAAMAAJ\&pg=PA3\#v=onepage\&q\&f=false. 
The search-incident-to-arrest doctrine generally allows a law enforcement officer to search items on an arrestee's person as well as objects within an arrestee's immediate control. ${ }^{5}$ This doctrine was developed to further the legitimate government interests of preservation of evidence and officer safety, ${ }^{6}$ but its recent application to electronic devices has proven a weighty endeavor for the lower courts. While the Supreme Court has yet to offer guidance, the issue of how to apply the text of the Fourth Amendment to current technology is percolating in the lower courts with inconsistent results.

Adhering to analogous Supreme Court precedent regarding physical items ${ }^{7}$ and allowing unconstrained searches of phone data may yield undesirable results. For example, suppose an individual is pulled over by a police officer for rolling through a stop sign. The police officer then lawfully arrests the individual for the traffic violation and proceeds to search his person, which predictably yields a smartphone. The officer activates the phone and begins perusing its contents-emails, photos, browser history, contacts, and text messages. The officer encounters photos of the arrestee's significant other posing nude in sexually suggestive poses, which the officer shares with his colleagues at the scene. This is precisely what happened in Newhard $v$. Borders, where the court found that the officers did not violate any "“clearly established' constitutional right ... under the Fourth Amendment." 8 The officers' intrusion is surely shocking; however, the Supreme Court's current stance on the search-incident-to-arrest doctrine seems to allow this government intrusion.

This Note describes why treating smart phones as traditional physical containers is irrational and proposes that cell phone searches incident to arrest be treated similar to home searches. Specifically, the amount of highly private data now stored on phones - text messages, bank records, medical records, photographs, etc.- - justifies the need for a search warrant or exceptional circumstances before law enforcement can access a phone's data. Part II of this Note provides a brief overview of the Fourth Amendment and discusses the formation of the search-incident-to-arrest

5. Chimel v. California, 395 U.S. 752, 762-63 (1969).

6. See id. at 763 (discussing the justifications for the search-incident-to-arrest doctrine).

7. See United States v. Robinson, 414 U.S. 218, 235 (1973) ("[A] search incident to the arrest requires no additional justification.”); see also New York v. Belton, 453 U.S. 454, 460 (1981) ("[W] hen a policeman has made a lawful custodial arrest of the occupant of an automobile, he may ... search the passenger compartment ... [and] any containers found within the passenger compartment. ..."), abrogated by Arizona v. Gant, 556 U.S. 332, 343-44 (2009).

8. 649 F. Supp. $2 d$ 440, 450 (W.D. Va. 2009). 
doctrine as well as how lower courts have applied the doctrine to cell phone searches. The focal case discussed is United States v. FloresLopez, decided by the Seventh Circuit in February 2012..$^{9}$ In FloresLopez, the court addressed many issues courts commonly face on this topic and upheld the warrantless search of an arrestee's phone to obtain the phone's own number. ${ }^{10}$ This case illustrates how treating phones as traditional physical objects does not provide phones with the Fourth Amendment protection their contents deserve. Part III analyzes the Seventh Circuit's decision, cautions against extending the Supreme Court's recent holding in Arizona v. Gant ${ }^{11}$ to cell phone searches, and argues for increasing the protection of cell phone data by treating a phone similar to a house for Fourth Amendment purposes.

\section{BACKGROUND}

\section{A. Fourth Amendment: Warrant and Reasonableness Requirements}

\section{The Fourth Amendment guarantees:}

The right of the people to be secure in their persons, houses, papers, and effects, against unreasonable searches and seizures, shall not be violated, and no Warrants shall issue, but upon probable cause, supported by Oath or affirmation, and particularly describing the place to be searched, and the persons or things to be seized. ${ }^{12}$

Based on this text, searches conducted "outside the judicial process" violate the warrant clause and are presumptively unreasonable, with several exceptions. ${ }^{13}$ Judicial approval for a search "interpose[s] a magistrate between the citizen[s] and police" because "the right of privacy [is] deemed too precious to entrust to the discretion of those whose job is the detection of crime ...."14 The United States Supreme Court has repeatedly expressed its "strong preference" that searches require a warrant ${ }^{15}$

\footnotetext{
9. 670 F.3d 803 (7th Cir. 2012).

10. Id. at 810 .

11. 556 U.S. 332 (2009) (holding that police may search a vehicle incident to a recent occupant's arrest if there is reason to believe the vehicle contains evidence of the arrest's offense).

12. U.S. CONST. amend. IV.

13. Katz v. United States, 389 U.S. 347, 357 (1967).

14. McDonald v. United States, 335 U.S. 451, 455 (1948).

15. See, e.g., Kentucky v. King 131 S. Ct. 1849, 1856 (2011) (“[T]his Court has inferred that a warrant must generally be secured."); Ornelas v. United States, 517 U.S. 690, 699 (1996) ("The Fourth Amendment demonstrates a "strong preference for searches conducted pursuant to a warrant ...."” (quoting Illinois v. Gates, 462 U.S. 213, 236 (1983))); Katz, 389 U.S. at 357 (“'Over and
} 
and has even labeled unbounded police discretion in the field "evil.",16

Reasonableness - the hallmark of the Fourth Amendment - is "predominantly an objective inquiry." 17 This is largely a fact-based exercise where all facts, evaluated objectively under the circumstances, are taken into account in deciding whether a search was reasonable. ${ }^{18}$ More specifically, the degree to which a search intrudes upon an individual's privacy is weighed against the search's furtherance of a legitimate government interest; thus, more intrusive searches require a higher level of justification. ${ }^{19}$ Current Fourth Amendment jurisprudence strives to protect an individual's reasonable and justifiable expectations of privacy. ${ }^{20}$

\section{B. Warrant Requirement Exception: Search Incident to Arrest}

\section{Supreme Court Formation of the Search-Incident-to-Arrest Doctrine}

The search incident to lawful arrest is one of the several exceptions to the warrant requirement. ${ }^{21}$ A search incident to a lawful arrest allows an officer to search an arrestee's person and the area within the arrestee's immediate control, which is defined as the space from which the arrestee could obtain a weapon or destructible evidence. ${ }^{22}$ The Supreme Court provided these boundaries in Chimel v. California, where it allowed the warrantless search of an arrestee based on concerns of officer safety and preservation of evidence. ${ }^{23}$ The search-incident-to-arrest doctrine allows officers to warrantlessly search many places under certain circumstances, including arrestees' vehicles, ${ }^{24}$ homes, ${ }^{25}$ and containers carried on their

\footnotetext{
again this Court has emphasized that the mandate of the (Fourth) Amendment requires adherence to judicial processes,' and that searches conducted outside the judicial process, without prior approval by judge or magistrate, are per se unreasonable under the Fourth Amendment — subject only to a few specifically established and well-delineated exceptions." (quoting United States v. Jeffers, 342 U.S. $48,51(1951)))$.

16. Delaware v. Prouse, 440 U.S. 648,661 (1979).

17. Ashcroft v. al-Kidd, 131 S. Ct. 2074, 2080 (2011) (quoting City of Indianapolis v. Edmond, 531 U.S. $32,47(2000))$.

18. Id.

19. United States v. Knights, 534 U.S. 112, 118-19 (2001).

20. See United States v. Jones, 132 S. Ct. 945, 950 (2012) (collecting modern cases applying the "reasonable expectation of privacy" standard).

21. United States v. Robinson, 414 U.S. 218, 224 (1973).

22. Arizona v. Gant, 556 U.S. 332, 339 (2009).

23. Chimel v. California, 395 U.S. 752, 763 (1969).

24. Gant, 556 U.S. at 343.

25. Chimel, 395 U.S. at 763 .
} 
person. ${ }^{26}$ This exception to the warrant requirement is justifiable under the reasonableness clause of the Fourth Amendment because individuals have a reduced expectation of privacy once placed under arrest. ${ }^{27}$

The search-incident-to-arrest doctrine drastically expanded after Chimel. In United States v. Robinson, the defendant was subjected to a pat-down search subsequent to his arrest for driving with a revoked license. $^{28}$ The search revealed a cigarette packet - a physical containerin Robinson's breast pocket, which the officer opened to find heroin capsules. ${ }^{29}$ The Court validated the search and stated that an officer's "extended exposure" while detaining and transporting any arrestee is substantial enough to permit such a search regardless of any concern for officer safety or preservation of evidence. ${ }^{30}$ Thus, officers were given authority to search the person of lawful arrestees - and containers on their person or in their immediate control - without any further justification. $^{31}$

Soon after Robinson, the Court refined its Fourth Amendment search-incident-to-arrest jurisprudence relating to containers associated with the arrestee. In New York v. Belton, a container was defined as "any object capable of holding another object." 32 The Court decided such containers may be searched whether they are open or closed. ${ }^{33}$ Further channeling Robinson's precedent, the Court stated "the justification for the search is not that the arrestee has no privacy interest in the container, but that the lawful custodial arrest justifies the infringement of any privacy interest the arrestee may have." ${ }^{34}$ The Court added that the size of the container was of no consequence; opening and searching any container on the arrestee's person or within his immediate control was reasonable. ${ }^{35}$ As in Robinson, the Court stressed a discretion-limiting standard, forming a "straightforward rule, easily applied, and predictably enforced" to avoid litigation contemplating whether a search was justi-

\footnotetext{
26. See Robinson, 414 U.S. at 236.

27. United States v. Gomez, 807 F. Supp. 2d 1134, 1142 (S.D. Fla. 2011).

28. Robinson, 414 U.S. at 220-23.

29. Id. at 223.

30. Id. at 234-35.

31. Id. at 235 .

32. New York v. Belton, 453 U.S. 454, 460 n.4 (1981), abrogated by Arizona v. Gant, 556 U.S. 332, 343-44 (2009).

33. Id. at 461.

34. Id. (emphasis added).

35. See $i d$. (explaining that a container may be searched even if it is not capable of holding a weapon or any evidence of criminal conduct relating to the suspect's arrest).
} 
fied after the fact. ${ }^{36}$

\section{Search Incident to Arrest Limitations}

While no restrictions were imposed on what objects can be searched or the justification necessary for a search incident to arrest, the Chimel Court still required satisfaction of temporal and spatial requirements, as well as observance of the Fourth Amendment's reasonableness component. $^{37}$

The temporal and spatial elements of a search incident to arrest require that the search take place contemporaneously and within the "immediate vicinity" of the arrest. ${ }^{38}$ Generally, the immediate vicinity of an arrest includes anything within the arrestee's "reaching distance" at the time of arrest. ${ }^{39}$ If a search takes place outside either of these boundaries, and without probable cause or a warrant, then it is per se invalid. ${ }^{40}$ Recent cases suggest that, despite the liberal application of the searchincident-to-arrest doctrine in Robinson and Belton, temporal and spatial requirements provide narrow avenues for limiting these searches. ${ }^{41}$ Nonetheless, searches occurring later in time at the place of detention are generally within the temporal requirement. ${ }^{42}$

Although searches incident to arrest are generally considered reasonable, a search may be so intrusive that it becomes unreasonable and thus

36. Id. at 459 .

37. See id. at 457 (requiring the search be contemporaneous with the arrest and restricted to the "immediately surrounding area"); see also United States v. Gomez, 807 F. Supp. 2d 1134, 1144-45 (S.D. Fla. 2011) (discussing the temporal, spatial, and reasonableness limits of a search incident to arrest).

38. Gomez, 807 F. Supp. 2d at 1144 (citing Holmes v. Kucynda, 321 F.3d 1069, 1082 (11th Cir. 2003) (quoting Belton, 453 U.S. at 465)).

39. Id. at 1145 .

40. See United States v. Chadwick, 433 U.S. 1, 15 (1977) ("[W]arrantless searches of luggage or other property seized at the time of an arrest cannot be justified as incident to that arrest ... if the 'search is remote in time or place from the arrest. ..." (quoting Preston v. United States, 376 U.S. 364, 367 (1964))), abrogated by California v. Acevedo, 500 U.S. 565 (1991); see also Gomez, 807 F. Supp. $2 \mathrm{~d}$ at 1144 (stating that searches incident to arrest are limited by time and space).

41. See, e.g., United States v. Wells, 347 F.3d 280, 287 (8th Cir. 2003) (invalidating a search under the search-incident-to-arrest exception due to passage of time, but upholding the search on other grounds); Holmes v. Kucynda, 321 F.3d 1069, 1082-83 (11th Cir. 2003) (finding that a purported search incident to arrest of a suspect's bedroom and purse was unconstitutional because the search was temporally and physically remote from the arrest).

42. See United States v. Edwards, 415 U.S. 800, 807 (1974) (“[O]nce the accused is lawfully arrested and is in custody, the effects in his possession at the place of detention that were subject to search at the time and place of his arrest may lawfully be searched and seized without a warrant even though a substantial period of time has elapsed ....”). 
invalid under the Fourth Amendment. ${ }^{43}$ For instance, a strip search incident to a lawful arrest at the scene of arrest may be unreasonable under ordinary circumstances. ${ }^{44}$ While initially applying the search-incidentto-arrest doctrine expansively, the Supreme Court also anticipated instances where an "extreme or patently abusive" search incident to arrest could violate an individual's rights so severely that it would not be valid under this doctrine. ${ }^{45}$

\section{Arizona v. Gant: Vehicle Search-Incident-to-Arrest Doctrine Altered}

In Arizona v. Gant, the Supreme Court returned to Chimel's original justifications and adopted a new reason-to-believe standard in the context of vehicle searches incident to arrest. ${ }^{46}$ Gant was arrested for driving on a suspended license and was handcuffed and placed in the back of a police car while two officers searched his vehicle. ${ }^{47}$ The officers found a gun and a bag of cocaine inside the vehicle; and Gant moved to suppress the evidence on the grounds that the vehicle search violated his Fourth Amendment rights. ${ }^{48}$ The Court expressed concern that adhering to Belton - which allowed officers to automatically search a vehicle's passenger compartment and any containers within upon an occupant's arrest without additional justification ${ }^{49}$ - would yield an undesirable result of giving police officers "unbridled discretion," implicating the "central concern underlying the Fourth Amendment" of protecting citizens from unreasonable government intrusions. ${ }^{50}$ The Court ultimately rejected the Belton holding in the context of automobile searches, citing the "checkered history" of the search-incident-to-arrest exception. ${ }^{51}$ Instead, the Court fell back on Chimel's justifications and held that a vehicle search

\footnotetext{
43. Gomez, 807 F. Supp. 2d at 1145.

44. See, e.g., Mary Beth G. v. City of Chi., 723 F.2d 1263, 1270-71 (7th Cir. 1983) (implying a strip search incident to lawful arrest may violate the Fourth Amendment's reasonableness requirement under ordinary circumstances if not done at the police stationhouse (citing Illinois v. Lafayette, 462 U.S. 640, 645 (1983))); but see Florence v. Bd. of Chosen Freeholders, 132 S. Ct. 1510, 1517 (2012) (allowing correctional facilities to invasively search detainees when being admitted pursuant to policy seeking to detect contraband).

45. See United States v. Robinson, 414 U.S. 218, 236 (1973) (implying "extreme or patently abusive" searches incident to arrest could be unconstitutional).

46. Arizona v. Gant, 556 U.S. 332 (2009).

47. Id. at 336 .

48. Id.

49. New York v. Belton, 453 U.S. 454, 460 (1981), abrogated by Arizona v. Gant, 556 U.S. 332, 343-44 (2009).

50. Gant, 556 U.S. at 345.

51. Id. at 350 .
} 
incident to arrest must be justified by a concern for officer safety, specifically requiring the arrestee be "unsecured and within reaching distance of the passenger compartment at the time of the search." 52 Additionally, the Court diverged from Chimel's rationale by authorizing a unique rule allowing officers to search a vehicle following an arrest "when it is 'reasonable to believe evidence relevant to the crime" may be found. ${ }^{53} \mathrm{Be}$ cause there was no threat to the officers and no reason to believe further evidence of driving with a suspended license would be found, the search of the vehicle was unreasonable according to the court. ${ }^{54}$ Notably, this holding applies only to vehicle searches; a full search of an arrestee's person upon arrest has not been similarly altered by the Supreme Court, ${ }^{55}$ but some lower courts have applied an approach similar to Gant when examining cell phone searches. ${ }^{56}$

\section{Search Incident to Arrest: Application to Cell Phone Searches}

The Supreme Court has yet to rule on whether a cell phone's contents may be searched incident to arrest. ${ }^{57}$ The Court granted certiorari in 2010 on a similar issue regarding an employer's search of a pager, but, to avoid "elaborating too fully on the Fourth Amendment implications of emerging technology before its role in society has become clear," the Court decided the case on other grounds. ${ }^{58}$ Recent decisions in lower courts reflect differing views on how to apply the search-incident-toarrest doctrine to cell phones. Some courts treat cell phones as traditional physical objects or containers under Belton, but a significant number of courts have diverged from this approach and discussed whether a new standard should be formulated to evaluate cell phone searches.

\footnotetext{
52. Id. at 343 .

53. Id. (quoting Thornton v. U.S., 541 U.S. 615, 632 (2004) (Scalia, J., concurring)).

54. Id. at 344 .

55. People v. Taylor, 296 P.3d 317, 322 (Colo. App. 2012) (“[T]he United States Supreme Court ... has [not] directly considered the issue of whether a search incident to arrest may include a search of a cell phone's contents, and if it does, how thorough the search might be."), cert. denied, No. 12SC542, 2012 WL 134432 (Colo. Jan. 7, 2013).

56. E.g., United States v. Quintana, 594 F. Supp. 2d 1291, 1300 (M.D. Fla. 2009) (discussing how police "may be justified in searching the contents of a cell phone for evidence related to the crime of arrest").

57. Jana L. Knott, Note, Is There an App for That? Reexamining the Doctrine of Search Incident to Lawful Arrest in the Context of Cell Phones, 35 OKLA. CiTY U. L. REV. 445, 449 (2010).

58. City of Ontario v. Quon, 130 S. Ct. 2619, 2629 (2010).
} 


\section{Upholding the Search: Traditional Container Approach}

Many courts have applied the search-incident-to-arrest doctrine by treating a cell phone as if it were a physical object like the cigarette packet in Robinson or a container as described in Belton. ${ }^{59}$ Under either precedent, officers are free to peruse an arrestee's phone following a custodial arrest. ${ }^{60}$

In United States v. Finley, the Fifth Circuit decided a cell phone can be searched incident to arrest in the same manner as a traditional container. ${ }^{61}$ In this case, police arrested the defendant in connection with a controlled buy of methamphetamine and seized his cell phone. ${ }^{62}$ After transporting the defendant to a co-suspect's residence, officers interviewed the defendant regarding his past drug involvement. ${ }^{63}$ During the interrogation, the questioning officer searched through the defendant's call records and text messages, several of which implicated him in drug trafficking. ${ }^{64}$ The defendant argued this evidence should have been suppressed because his cell phone was like a closed container. ${ }^{65}$ The Fifth Circuit disposed of this argument with little discussion by applying the broad reasoning from Belton and Robinson, which states that officers need no justification to search a closed container within the arrestee's immediate control. $^{66}$

Similar rulings apply Robinson and Belton but acknowledge that categorizing cell phones as physical objects just like cigarette packets is an uncomfortable analogy. In People v. Diaz, the California Supreme Court cited the large amount of information cell phones are capable of holding

59. E.g., United States v. Finley, 477 F.3d 250, 260 (5th Cir. 2007) (allowing the search incident to arrest of a cell phone because the "permissible scope of a search incident to a lawful arrest extends to containers found on the arrestee's person"); People v. Diaz, 244 P.3d 501, 507 (Cal. 2011) (stating that there is "no legal basis" for altering the scope of a search incident to arrest based on the character of the item).

60. See New York v. Belton, 453 U.S. 454, 461 (1981) (“[A] container may . . be searched whether it is open or closed, since ... the lawful custodial arrest justifies the infringement of any privacy interest the arrestee may have."), abrogated by Arizona v. Gant, 556 U.S. 332, 343-44 (2009); United States v. Robinson, 414 U.S. 218, 235 (1973) ("[I]n the case of a lawful custodial arrest a full search of the person is not only an exception to the warrant requirement of the Fourth Amendment, but is also a 'reasonable' search under that Amendment.").

61. Finley, 477 F.3d at 260.

62. Id. at $253-54$.

63. Id. at 254 .

64. Id.

65. Id. at 260 .

66. Id. 
but dismissed this fact as inconsequential. ${ }^{67}$ The opinion stated that "the high court has expressly rejected the view that the validity of a warrantless search depends on the character of the searched item." ${ }^{68}$ Further, the court declared that all containers should be treated the same because distinguishing between "worthy" and "unworthy" containers would pose a difficult line-drawing problem. ${ }^{69}$ Ignoring the dissent's assertion that Fourth Amendment container law had developed without current technology in mind, ${ }^{70}$ the court instead validated the search by treating the cell phone at issue like an article of clothing or cigarette package, which can be legally searched incident to arrest under Supreme Court precedent. $^{71}$

Another typical search incident to arrest case, United States $v$. Gomez, upheld the warrantless search of a cell phone but suggested deeper concerns about the intrusiveness and discretionary decisions involved. $^{72}$ In this drug-related arrest, the search was considered reasonable under Belton and Gant because the defendant's cell phone was within reaching distance at the time of arrest, and separately, the officers had reason to believe the phone contained evidence of the crime. ${ }^{73}$ The U.S. District Court for the Southern District of Florida analogized the phone to a wallet or purse - both searchable incident to arrest - but expressed apprehension at grouping the "ever-advancing technology of cell phones" with other Belton containers. ${ }^{74}$ Moreover, the court stated that, regardless of its views on technology and containers, it was obligated to apply the Supreme Court's precedent. ${ }^{75}$ The court held that "a short, limited perusal" of a phone's call history to gain relevant evidence was reasonable, but this holding was accompanied by regret for failing to delineate a clear standard for future cases. ${ }^{76}$ As in Diaz, the Gomez court noted

67. See People v. Diaz, 244 P.3d 501, 506 (Cal. 2011) (noting that analogous Supreme Court precedents indicate the scope of a warrantless search is not altered by the nature of the seized item).

68. Id. at 507 .

69. Id.

70. Id. at 516-17 (Werdegar, J., dissenting) ("The United States Supreme Court's holdings on clothing and small spatial containers were not made with mobile phones, smartphones and handheld computers-none of which existed at the time-in mind.").

71. Id. at $505-06$.

72. 807 F. Supp. 2d 1134 (S.D. Fla. 2011).

73. Id. at 1145 .

74. Id. at 1146.

75. See id. ("Even though we may disagree with the application of that post-Chimel line of cases ... we are constrained to apply the law as the Supreme Court currently pronounces it.").

76. See id. at 1149 (stating that the court's own holding contributed to the "present uneasiness" involved in searching cell phones incident to arrest). 
that such a bright-line rule would be difficult to formulate in light of advancements in technology. ${ }^{77}$ After applying Supreme Court precedent and discussing the concerns involved, the court acknowledged that this technological problem may be best solved with technology, rather than by judicial opinion, by suggesting individuals should password protect their electronic devices. ${ }^{78}$

Even though these decisions deem cell phone searches reasonable, some courts expressly recognize the existence of a threshold where such a search may become unreasonable. The Gomez court, for instance, denied giving officers "carte blanche" to indefinitely search every detail of an arrestee's phone in light of the Fourth Amendment's reasonableness requirement. ${ }^{79}$ Similarly, in United States v. Gordon, the U.S. District Court of Hawaii implied that police may be restricted to search only noncomputer-like contents of modern cell phones under existing precedent. ${ }^{80}$

2. Denying the Search: Phones Not Treated as Traditional Containers

Some courts have invalidated cell phone searches incident to arrest by rejecting the argument that cell phones are traditional Belton containers that may be searched without further justification. ${ }^{81}$ These opinions agree that the judiciary is ignoring Belton's definition of a container, thereby extending Chimel beyond its intended reach. ${ }^{82}$ A recent opinion from the Supreme Court of Ohio rejected Belton's application to cell phones, stating that Belton's definition of a container excluded technological devices because Belton described a receptacle capable of storing a physical object inside of itself. ${ }^{83}$ The Ohio court also stated that cell phones are unlike address books or pagers - items previously ruled searchable-because cell phones store more information and are multi-

77. Id. at $1149-50$.

78. See id. at 1150 (admitting that the court "do[esn't] have the answer," but suggesting the preliminary solution of individuals safeguarding their devices with password protection).

79. Id. at 1149 .

80. United States v. Gordon, 895 F. Supp. 2d 1011, 1025 (D. Haw. 2012) (“And importantly, the only evidence taken from Gordon's cellular telephone (snapshots of its call history and its contact list) are not characteristics of a computer-like smart phone.").

81. E.g., United States v. Wall, No. 08-60016-CR, 2008 WL 5381412, at *3 (S.D. Fla. Dec. 22, 2008), aff'd, 343 F. App'x 564 (11th Cir. 2009); United States v. Park, No. CR 05-373 SI, 2007 WL 1521573, at *8 (N.D. Cal. May 23, 2007); State v. Smith, 920 N.E.2d 949, 953-54 (Ohio 2009).

82. See, e.g., Wall, 2008 WL 5381412, at *3-4 (stating that the cell phone search was not justified by a threat to officer safety or preservation of evidence); Park, 2007 WL 1521573, at *8 (noting a cell phone search "go[es] far beyond the original rationales for searches incident to arrest").

83. Smith, 920 N.E.2d at 954. 
functional. ${ }^{84}$ These facts gave the defendant a "reasonable and justifiable expectation of a higher level of privacy" in his cell phone, which therefore required a warrant to search. ${ }^{85}$

Other courts have fallen back on the original justifications in Chimel and have required a threat to officer safety or the need to prevent the destruction of evidence to search an arrestee's phone. In United States $v$. Wall, the U.S. District Court of Florida noted that once a phone has been confiscated from the arrestee's person, it is neither a danger to officers nor are its contents at risk of destruction. ${ }^{86}$ Based on this analysis, investigatory searches undertaken for the procurement of evidence would be considered unreasonable without a warrant. ${ }^{87}$

Courts invalidating cell phone searches further justify this result by discussing the implications of a contrary ruling. In Schlossberg v. Solesbee, an Oregon district court evaluated the search incident to arrest of a digital camera, ${ }^{88}$ which is similar to a cell phone search because smartphones incorporate camera and picture storage functions. ${ }^{89}$ This opinion declared warrantless searches of cameras - and all similar electronic devices - unreasonable under the Fourth Amendment because of the large amount of private information stored within. ${ }^{90}$ Additionally, the court expressed unease over rulings like Gomez, which allow a limited perusal of certain information within the phone, noting the impracticality of requiring officers to distinguish between searchable and nonsearchable content or devices. ${ }^{91}$ In United States v. Park, the court took this analysis a step further and discussed the "far-ranging consequences" of allowing such discretion, noting that an officer may still inadvertently encounter highly private information in the course of a limited search. ${ }^{92}$

\section{United States v. Flores-Lopez}

The Seventh Circuit recently upheld a warrantless search incident to

84. Id. at 955 .

85. Id.

86. Wall, 2008 WL 5381412, at *3-4.

87. Park, 2007 WL 1521573, at *8-9.

88. 844 F. Supp. 2d 1165, 1166 (D. Or. 2012).

89. See, e.g., APPLE, http://www.apple.com/iphone/features/ (last visited Sept. 17, 2013) (describing iPhone's camera feature).

90. Schlossberg, 844 F. Supp. 2d at 1170.

91. Id.

92. See Park, 2007 WL 1521573, at *8 (noting how a search may uncover medical records, personal letters, photos, and financial information). 
arrest of a cell phone in February 2012..$^{93}$ Although it ultimately validated the "minimally invasive" search in light of the remote risk of evidence destruction, ${ }^{94}$ the court's discussion of phones and the search-incident-toarrest doctrine provides insight into future court dispositions and exposes issues previously unaddressed.

\section{a. Facts of the Case}

In Flores-Lopez, the defendant's arrest resulted from a controlled drug buy in which a government informant arranged to purchase a pound of methamphetamine from a dealer named Santana-Cabrera. ${ }^{95}$ SantanaCabrera, overheard by the informant, called his own supplier, FloresLopez, to arrange delivery of the methamphetamine to a garage. ${ }^{96}$ Flores-Lopez arrived with the methamphetamine, and he and SantanaCabrera were subsequently arrested. ${ }^{97}$ Incident to his arrest, law enforcement officers seized a cell phone from Flores-Lopez's person. ${ }^{98}$ While still at the site of arrest, officers searched Flores-Lopez's phone for its own number, which allowed the officers to later subpoena three months of call history from the phone's service provider. ${ }^{99}$

The district court sentenced Flores-Lopez to ten years in prison for drug-related offenses. ${ }^{100}$ On appeal, Flores-Lopez argued that the search of his phone was unreasonable under the Fourth Amendment because it was not conducted pursuant to a warrant. ${ }^{101}$ Thus, Flores-Lopez argued the call history the government presented at trial linking him to drug distribution was the fruit of an unconstitutional search and should have been suppressed. ${ }^{102}$

\section{b. The Seventh Circuit's Opinion}

Writing for the Seventh Circuit, Judge Posner began his opinion by

\footnotetext{
93. United States v. Flores-Lopez, 670 F.3d 803, 810 (7th Cir. 2012).

94. Id. at 809 .

95. Id. at 804 .

96. Id.

97. Id.

98. Id.

99. Id.

100. Id.

101. Id. at 805 .

102. Id.
} 
declaring "a modern cell phone is a computer."103 Next, Judge Posner stated that cell phones are containers because Belton's definition encompassed any object that can contain another object, including electronic data. ${ }^{104}$ The opinion noted the awkwardness of comparing computers to physical containers for Fourth Amendment purposes and acknowledged that cell phone searches invade privacy to a greater degree. ${ }^{105}$

Judge Posner next declined to apply Robinson's no-justificationnecessary approach to the search incident to arrest of the cell phone by pointing out implied limits to the search's reasonableness when officers encounter purely personal information unrelated to the crime. ${ }^{106}$ Using Robinson's and Chimel's justifications for evaluating the search, Judge Posner declared that once the phone was seized by police, there was no risk of harm to the officers and only a slight chance the phone's contents could be destroyed by "remote wiping." 107 The defendant countered this risk of evidence destruction by stating that the police could have eliminated this threat by placing the phone in a Faraday bag - a bag that makes remote intervention impossible by isolating its contents from network and internet signals - or copying the phone's data for preservation. ${ }^{108}$ Nonetheless, the court dismissed these proposed remedies as too burdensome on police officers. ${ }^{109}$ Thus, the Seventh Circuit upheld the search because the slight risk of evidence destruction justified the "minimally invasive" search for the phone's own number "provided it's no more invasive than . . . a frisk, or the search of a conventional container." 110 Therefore, the limited search to discover the phone's number was within the boundaries of Robinson. ${ }^{111}$

Judge Posner closed the opinion by tailoring the holding to the narrow set of facts before the court - a very limited search of a cell phone incident to a lawful arrest. ${ }^{12}$ Judge Posner listed exceptional circumstances that could warrant a different outcome, but stated that specific

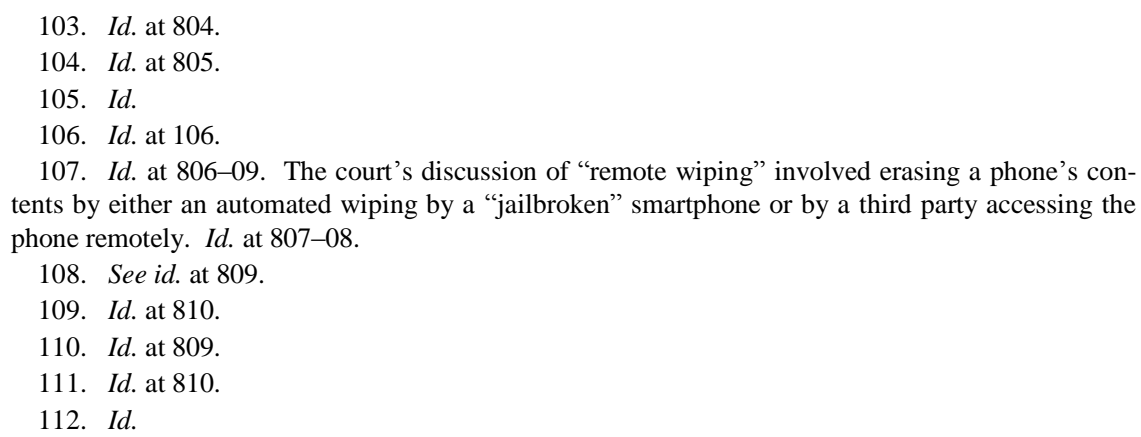


situations that could warrant a more in-depth search were "questions for another day."

\section{ANALYSIS}

By deciding the narrow issue presented in Flores-Lopez, the Seventh Circuit delivered insight regarding the current state of cell phone searches incident to arrest, yet left many issues open for debate. This Section will begin by deconstructing the court's rationale for upholding the search, highlight how searching a phone for evidence of other coconspirators is not authorized by Chimel, and detail how Faraday bags could eliminate any risk of evidence destruction. Next, this Section will caution against the Supreme Court applying vehicle search principles from Arizona v. Gant to cell phones because of the potential for highly invasive searches under that precedent. Finally, this Section proposes treating cell phone searches similar to home searches to better protect the highly private data found on modern phones.

\section{A. Flores-Lopez: Analyzing the Seventh Circuit's Opinion}

\section{Allowing a Limited Search Based on a Small Risk of Evidence Destruction}

In upholding the Flores-Lopez search based on its minimal invasiveness and the small risk that evidence would be destroyed, the Seventh Circuit essentially applied the same analysis as Gomez - a brief "perusal" of an arrestee's phone for relevant evidence of the crime is reasonable. ${ }^{114}$ Like the Gomez court, Judge Posner briefly discussed the boundaries involved in searching an arrestee's phone but declined to assert a standard that would justify a more in-depth search. ${ }^{115}$ Judge Posner's opinion aligned with other lower courts in recognizing the vast amount of personal information stored on phones and noting the undesirable consequences of allowing full-blown searches as authorized by Robinson and its progeny. ${ }^{116}$

113. Id.

114. United States v. Gomez, 807 F. Supp. 2d 1134, 1149 (S.D. Fla. 2011).

115. See Flores-Lopez, 670 F.3d at 810 (stating that the circumstances that would justify a more in-depth search of a cell phone's contents "are questions for another day").

116. Compare United States v. Robinson, 414 U.S. 218, 235 (1973) (requiring no additional justification for a search incident to arrest), with Gomez, 807 F. Supp. 2d at 1149 (limiting the scope of a search incident to arrest to a "short, limited perusal" for relevant evidence). 
Yet, allowing the search based on its minimal invasiveness seems contrary to much of Judge Posner's discussion. The opinion began with cautionary words about the higher degree of intrusion implicit in searching a cell phone as opposed to a conventional container. ${ }^{117}$ Judge Posner made clear that cell phones deserve a higher expectation of privacy than traditional physical containers; nevertheless, he implied the cell phone search at issue was "minimally invasive." 118 These propositions seem to be at odds with one another - how can the search of an object warranting an elevated level of privacy be "minimally invasive?" The court discounts the search's intrusiveness by ratifying the search after the fact because only innocuous information was discovered. This model of justifying "limited" searches post hoc could lead to objectionable invasions of individuals' privacy, as law enforcement officers can never know in advance what type of information will be exposed upon accessing a cell phone. ${ }^{119}$ Leaving this discretion to officers in the field is contrary to Fourth Amendment foundational principles and sounds of the "evil" about which the Framers and the Supreme Court have repeatedly warned. ${ }^{120}$ Instead of relying on the discretionary acts of police officers responding to the possibly illusory risk of evidence destruction, this situation necessitates a warrant to "interpose[] a magistrate between the citizen and the police." 121

Additionally, the risk of evidence destruction - the court's justification for the search - was likely overstated. The court admits the possibility of Flores-Lopez or one of his cohorts remotely wiping the phone's contents was "not probable," 122 but even this characterization was exaggerated. The likelihood that a small drug ring selling their product from a garage would utilize remote wiping or "jail-broken" phones seems miniscule at best. Even if this technology were used, the evidence would

117. Flores-Lopez, 670 F.3d at 805 ("A modern cell phone ... is quite likely to contain ... a vast body of personal data. The potential invasion of privacy in a search of a cell phone is greater than in a search of a 'container' in a conventional sense ....").

118. See id. at 809.

119. See id. at 806 ("At the touch of a button a cell phone search becomes a house search ...."); see also Newhard v. Borders, 649 F. Supp. 2d 440, 444 (W.D. Va. 2009) (upon searching a phone without a warrant, police officers discovered sexual photos of arrestee's girlfriend and shared them with other officers for their "viewing and enjoyment").

120. See, e.g., Delaware v. Prouse, 440 U.S. 648, 661 (1979) (labeling "standardless and unconstrained [officer] discretion" as evil and noting how previous Supreme Court decisions have "insisted that the discretion of the official in the field be circumscribed").

121. Schlossberg v. Solesbee, 844 F. Supp. 2d 1165, 1171 (D. Or. 2012) (quoting McDonald v. United States, 335 U.S. 451, 455 (1948)).

122. Flores-Lopez, 670 F.3d at 809. 
still be available through other means such as the cellular provider's database. ${ }^{123}$ By allowing the search incident to arrest, Judge Posner avoided evidence suppression and aided in convicting a criminal, but even this worthy cause does not justify stretching Chimel's rationale beyond its intended limits. ${ }^{124}$

\section{A Cell Phone Search Leading to Arrest of Other Co-Conspirators}

The Seventh Circuit also suggested limited cell phone searches incident to arrest could help law enforcement seize co-conspirators. ${ }^{125}$ This proposition is not encompassed by either of Chimel's original justifications - officer safety and preservation of evidence - upon which the Seventh Circuit relied in Flores-Lopez. ${ }^{126}$ Thus, searching an arrestee's phone for evidence that is not at risk of destruction or concealment violates these seminal Fourth Amendment principles because "'the mere fact that law enforcement may be made more efficient can never by itself justify disregard of the Fourth Amendment.",127 While seizing coconspirators may be a desirable result for law enforcement, Chimel's justifications do not authorize this type of unsubstantiated rummaging as an exception to the Fourth Amendment's warrant requirement. ${ }^{128}$

\section{Preservation of Evidence and Faraday Bags}

Judge Posner stressed the need to access a phone before its contents could be destroyed, but quickly dismissed the use of Faraday bags which could combat this risk. ${ }^{129}$ A faraday bag is "essentially an aluminum-foil

123. See id. at 808 ("Wiped data may be recovered in a laboratory ...."); see also Joshua Earnes, Note, Criminal Procedure-"Can You Hear Me Now?': Warrantless Cell Phone Searches and the Fourth Amendment; People v. Diaz, 224 P.3d 501 (Cal. 2011), 12 Wyo. L. REV. 483, 49798 (2012) (stating that the destruction of evidence rationale does not apply to phone searches incident to arrest because most data is stored by the cellular provider).

124. See New York v. Belton, 453 U.S. 454, 469 (1981) (Brennan, J., dissenting) (“"[T]he mere fact that law enforcement may be made more efficient can never by itself justify disregard of the Fourth Amendment."' (quoting Mincey v. Arizona, 437 U.S. 385, 393 (1978))), abrogated by Arizona v. Gant, 556 U.S. 332, 343-44 (2009).

125. Flores-Lopez, 670 F.3d at 810.

126. Id. at 806 .

127. Belton, 453 U.S. at 469 (Brennan, J., dissenting) (quoting Mincey v. Arizona, 437 U.S. 385 , 393 (1978)).

128. See Chimel v. California, 395 U.S. 752, 763 (1969) (discussing officer safety and destruction of evidence as the sole justifications for the search-incident-to-arrest doctrine).

129. See Flores-Lopez, 670 F.3d at 810 (discussing the burden Faraday bags would impose on police officers). 
wrap" 130 that safeguards a phone from any remote attempts to access, alter, or destroy its contents. ${ }^{131}$ Basically, a Faraday bag eliminates the phone's ability to communicate by blocking any outgoing or incoming transmissions. ${ }^{132}$ These devices are reusable and can be purchased for as little as thirty dollars. ${ }^{133}$ Judge Posner briefly discussed Faraday bags, but dismissed them as possible solutions because of the burden they would impose on police officers. ${ }^{134}$ Specifically, Judge Posner pointed to the burden of having police "traipse about with Faraday bags" as well as the hassle of training officers in their use. ${ }^{135}$ These concerns seem quite misplaced. Considering the amount of equipment already contained in the standard police cruiser, ${ }^{136}$ adding a phone-sized Faraday bag to the glove compartment would be trivial. Also, the training required would take seconds because using a Faraday bag is as simple as inserting the phone and sealing the bag. ${ }^{137}$ Given his concern that evidence may be wiped remotely, it is surprising Judge Posner did not advocate the use of Faraday bags, as they appear to affordably and effectively eliminate any risk of evidence destruction.

\section{B. Possible Supreme Court Solution: Applying Gant's "Reason-to- Believe" Standard to Cell Phone Searches Incident to Arrest}

The "reason-to-believe" standard was originally suggested by Justice Scalia in a concurring opinion in a vehicle search-incident-to-arrest case $^{138}$ and was adopted for such cases by the United States Supreme

130. Id. at 809 .

131. Charles E. MacLean, But, Your Honor, a Cell Phone is Not a Cigarette Pack: An Immodest Call for a Return to the Chimel Justifications for Cell Phone Memory Searches Incident to Lawful Arrest, 6 FED. CTS. L. REV. 37, 50 (2012).

132. See Mark Sutton, Faraday Bags Help Secure Seized Mobile Devices, ITP.NET (Aug. 26, 2011), http://www.itp.net/585942-faraday-bags-help-secure-seized-mobile-devices. Faraday bags block "non-static electric fields such as mobile phone signals." $I d$.

133. MacLean, supra note 131, at 50.

134. Flores-Lopez, 670 F.3d at 810.

135. Id.

136. See Ed Grabianowski, How Police Cars Work, HowSTUFFWorks, http://auto.howstuffworks.com/police-car3.htm (last visited Oct. 2, 2013) (detailing the immense amount of equipment carried by police vehicles).

137. See Simon Steggles, Phone Shield Faraday Bag-See It In Use, YouTube (Apr. 11, 2008), http://www.youtube.com/watch?v=FdYSj821hLo (last visited Oct. 2, 2013) (displaying the simplicity and effectiveness of Faraday bags in a twenty-three second video).

138. See Thornton v. United States, 541 U.S. 615, 629-32 (2004) (Scalia, J., concurring) (justifying a car search incident to arrest based on a "more general sort of evidence-gathering search" when there is a "reasonable belief" evidence of the crime may be found). 
Court in Arizona v. Gant several years later. ${ }^{139}$ This standard goes beyond Chimel's two justifications and allows searches incident to arrest when it is "reasonable to believe that evidence of the offense of arrest might be found." 140 Justice Scalia recommended this standard because the Court's search-incident-to-arrest doctrine was "stretche[d] ... beyond its breaking point." ${ }^{141}$ The Court applied this approach to vehicle searches incident to arrest in Gant, ${ }^{142}$ but lower courts have also extended the standard to apply to cell phone searches. ${ }^{143}$

When a phone search-incident-to-arrest case comes before the Supreme Court, the Justices may extend Gant's holding to cell phones; that is, allow searches based on either of Chimel's justifications or on a reason-to-believe standard that evidence of the crime will be found. As the majority in Gant permitted officers to discern on a case-by-case basis when a vehicle search is constitutional, ${ }^{144}$ it is possible that a cell phone search case could be handled similarly. Some have argued this would be a necessary extension beyond Chimel's justifications because cell phones are neither a threat to officer safety nor are their contents at risk of destruction. ${ }^{145}$ Additionally, some argue this standard would help law enforcement combat crime by shifting the search's objective from evidence-preservation to evidence-gathering. ${ }^{146}$ Also, commentators suggest the reason-to-believe standard would ostensibly limit the scope of cell phone searches to relevant evidence more so than the current search-incident-to-arrest doctrine. ${ }^{147}$

Nevertheless, the reason-to-believe standard is an unsatisfactory solution to this issue because it lacks grounding in Fourth Amendment jurisprudence and gives law enforcement officers too much discretion in

\footnotetext{
139. See Arizona v. Gant, 556 U.S. 332, 351 (2009) ("Police may search a vehicle incident to a recent occupant's arrest only if ... it is reasonable to believe the vehicle contains evidence of the offense of arrest.").

140. Id. at 335 .

141. Thornton, 541 U.S. at 625 (Scalia, J., concurring).

142. 556 U.S. $332,351(2009)$.

143. E.g., United States v. Quintana, 594 F. Supp. 2d 1291, 1300-01 (M.D. Fla. 2009) (drawing from Gant's oral arguments, this court applied a rule similar to what the Gant Court would adopt soon after).

144. See Gant, 556 U.S. at 360 (Alito, J., dissenting) (noting that the majority's rule "reintroduces the same sort of case-by-case, fact-specific decisionmaking that the Belton rule was adopted to avoid"),

145. Knott, supra note 57, at 474 .

146. Id. at 475 .

147. See id. at 473-74 (discussing various arguments in favor of the relatively restrictive Gant approach).
} 
the field. First, this test is not supported by any "doctrinal justification" because it authorizes extensive searches based on bare officer suspicion. ${ }^{148}$ Dissenting in Gant, Justice Alito noted how this standard was proposed without any "explanation of its origin or justification." 149 Fourth Amendment jurisprudence demands a higher degree of protection from the unconstrained officer discretion inherent in this standard. ${ }^{150} \mathrm{Se}$ cond, the reason-to-believe standard's application would likely create confusion. $^{151}$ Justice Alito's dissent in Gant remarked how the majority's rule would "confuse law enforcement officers and judges for some time to come." ${ }^{\prime 52}$ This standard has not been previously applied, and the Gant court did not define where "reason to believe" resides on the spectrum of probable cause and reasonable suspicion, ${ }^{153}$ thus adopting this standard would not align with Belton's insistence on a "straightforward . . . easily applied" rule. ${ }^{154}$ Finally, while this solution conceptually limits the scope of searches incident to arrest, the as-applied results may still reveal highly private information because it is nearly impossible to discern a digital file's relevance without viewing or reading its contents. ${ }^{155}$ Granting officers this discretion with the unclear reason-tobelieve standard could lead to confusion in application as well as egregious violations of individuals' rights. ${ }^{156}$ Consequently, accessing a phone's data under this standard may inadvertently reveal highly private information without any doctrinal support to justify the search.

148. Adam M. Gershowitz, The iPhone Meets the Fourth Amendment, 56 UCLA L. REv. 27, 49 (2008).

149. Gant, 556 U.S. at 356 (Alito, J., dissenting).

150. See Delaware v. Prouse, 440 U.S. 648, 661 (1979) (“[S]tandardless and unconstrained discretion is the evil the Court has discerned when in previous cases it has insisted that the discretion of the official in the field be circumscribed ....").

151. See Knott, supra note 57, at 477 (noting that confusion may ensue in lower courts because the Gant Court did not define "reason to believe").

152. Gant, 556 U.S. at 356 (Alito, J., dissenting).

153. Knott, supra note 57, at 477.

154. New York v. Belton, 453 U.S. 454, 459 (1981), abrogated by Arizona v. Gant, 556 U.S. 332, 343-44 (2009).

155. See United States v. Park, No. CR 05-375 SI, 2007 WL 1521573, at *8 (N.D. Cal. May 23, 2007) (discussing how the potential information stored on an electronic device makes the search of an electronic device "substantially more intrusive" than the search of a tangible object (quoting United States v. Arnold, 454 F. Supp. 2d 999, 1004 (C.D. Cal. 2006))).

156. See, e.g., Newhard v. Borders, 649 F. Supp. 2d 440, 444 (W.D. Va. 2009) (searching a phone without a warrant, police officers discovered sexual photos of arrestee's girlfriend and shared them with other officers for their "viewing and enjoyment"). 


\section{Proposed Solution: Treat a Cell Phone Like a Residence for Fourth Amendment Purposes}

With the knowledge that "crafting such a specific rule for a cell phone is very difficult," 157 this Note proposes that phone searches be treated like home searches for Fourth Amendment purposes. Thus, a search of a phone's contents would only be allowed after acquiring a warrant or pursuant to a carefully drawn exception to the warrant requirement. Justifying this admittedly bold standard is the fact that the Chimel justifications cannot be effectively applied to phones, ${ }^{158}$ and the fact that intimately private data once stored safely in the home-family photos, financial and medical records, love letters, and more-is now stored within smartphones. This private information, regardless of the medium on which it is stored, deserves Fourth Amendment protection worthy of its confidentiality. This standard is proposed not "to shield criminals" or make the phone "a safe haven for illegal activities" but "so that an objective mind might weigh the need to invade" an individual's privacy. ${ }^{159}$ Applying this standard to phones will increase privacy under the Fourth Amendment and, while inarguably restricting police officer's investigatory abilities, limit officer discretion in the field.

\section{Fourth Amendment Standard for Home Searches}

\section{a. Home Searches: Warrant or Probable Cause with Exigencies \\ Required}

The home is the pinnacle of Fourth Amendment protection: "With few exceptions, the question whether a warrantless search of a home is reasonable and hence constitutional must be answered no."160 Absent a warrant or probable cause coupled with exigent circumstances, physically intruding upon the home "by even a fraction of an inch" violates the Fourth Amendment. ${ }^{161}$ Thus, if a law enforcement officer cracked open a door to a home without proper authorization to reveal only the "nonintimate rug on the vestibule floor," that seemingly miniscule search would

157. United States v. Gomez, 807 F. Supp. 2d 1134, 1149 (S.D. Fla. 2011).

158. See Chimel v. California, 395 U.S. 752, 763 (1969) (justifying searches of individuals for the purpose of finding any weapons that may endanger a police officer or seizing any evidence that may be concealed or destroyed).

159. McDonald v. United States, 335 U.S. 451, 455 (1948).

160. Kyllo v. United States, 533 U.S. 27, 31 (2001).

161. Id. at 37 (quoting Silverman v. United States, 365 U.S. 505, 512 (1961)). 
be unreasonable. ${ }^{162}$ Even if a felony has been committed and officers have probable cause to believe incriminating evidence will be found, the warrantless search of a home is impermissible. ${ }^{163}$ Clearly, the judiciary has protected the home's sanctity at every turn.

To enter a residence, either a warrant or exceptional circumstances are required. ${ }^{164}$ Warrants must be particular and, as the Fourth Amendment demands, supported by probable cause. ${ }^{165}$ The warrant must also be supported by affidavit. ${ }^{166}$ These requirements "stay[] the hands of police" until an unbiased third-party magistrate can decide whether to allow government entry into the home. ${ }^{167}$ Exceptional circumstances to enter a home exist when "compelling reasons ... justify the absence of a search warrant." " 168 These compelling reasons include emergency aid, hot pursuit, and the "need to prevent the imminent destruction of evidence." 169 The emergency aid exigency applies when it is necessary for officers to enter in order to "render emergency assistance to an injured occupant or to protect an occupant from imminent injury." 170 The hot pursuit exigency is invoked when officers are in "hot pursuit" of a fleeing suspect who enters a private residence. ${ }^{171}$ In addition to the three exceptions above, officers may also enter and search a home after a property owner-or a person who possesses common authority over the premises-voluntarily agrees to the search. ${ }^{172}$

\section{b. Applying the Home Standard to Phones}

Applying this Fourth Amendment home search standard to phones means that, absent exceptional circumstances, police officers would need to obtain a warrant to search an arrestee's phone. As with a home search warrant, a phone search warrant would need to be issued upon probable cause and be supported by affidavit particularly describing the items to

\footnotetext{
162. Id.

163. See Payton v. New York, 445 U.S. 573, 587-88 (1980) (discussing how entering a home to search is unconstitutional "even when a felony has been committed and there is probable cause to believe that incriminating evidence will be found within").

164. See id. at 581-84.

165. Id. at 584 .

166. U.S. CONST. amend. IV ("supported by Oath or affirmation").

167. McDonald v. United States, 335 U.S. 451, 453 (1948).

168. Id. at 454 .

169. Kentucky v. King, 131 S. Ct. 1849, 1856 (2011) (internal citations omitted).

170. Id.

171. See id.

172. Illinois v. Rodriguez, 497 U.S. 177, 181 (1990).
} 
be searched. ${ }^{173}$ For instance, a warrant may call for the search of a phone's call history or text messages for evidence relating to a certain crime. The short delay in acquiring a warrant would be inconsequential, as the data within the phone is generally not subject to destruction because cell phone providers store call logs and text messages off-site for an extended period of time. ${ }^{174}$ Further, the phone's data may also be protected from destruction by using a Faraday bag. ${ }^{175}$

The exceptional circumstances that justify the warrantless entry of a home - consent, emergency aid, hot pursuit, and the preservation of evidence $^{176}$ - are not perfect fits for a cell phone, but may work in limited scenarios. Emergency aid may be applicable in the context of certain crimes. For example, criminals involved in kidnapping - or other crimes where a victim faces serious imminent danger - may have their phones searched incident to arrest. In these scenarios, it is important for police officers to immediately access the phone's contents in an effort to prevent possible harm to a victim. Hot pursuit, however, likely would not apply in the context of cell phones. Consent would likely be the most common reason for a police officer to perform an on-the-spot warrantless search of the arrestee's phone. If the arrestee voluntarily consents, ${ }^{177}$ an officer would be able to search the phone to the extent the arrestee allows. However, if an exigency does not exist and consent is not given, the officer would have to seek a warrant to search the phone's contents.

\section{Justification for Treating Phone Searches Like Home Searches}

The current jurisprudence regarding cell phone searches incident to arrest should be reworked because cell phones are not "containers" under Belton, and therefore do not fit within the scope of current Fourth Amendment search-incident-to-arrest analysis. ${ }^{178}$

\footnotetext{
173. See Groh v. Ramirez, 540 U.S. 551, 557 (2004) ("The Fourth Amendment requires that the warrant particularly describe the things to be seized ....").

174. Earnes, supra note 123, at 497.

175. See supra Part III.A.3 (discussing the effectiveness of Faraday bags).

176. King, 131 S. Ct. at 1856; Rodriguez, 497 U.S. at 181.

177. See Schneckloth v. Bustamonte, 412 U.S. 218, 227 (1973) (discussing consent in terms of whether, in light of the totality of all surrounding circumstances, consent was given voluntarily).

178. See United States v. Wall, No. 08-60016-CR, 2008 WL 5381412, at*3 (S.D. Fla. Dec. 22, 2008) (stating phones do not fit within the scope of current search-incident-to-arrest analysis). But see United States v. Gomez, 807 F. Supp. 2d 1134, 1144 (S.D. Fla. 2011) ("[I]t is undisputed that, even post-Gant, a cell phone found 'close to [the] Defendant' is also subject to a search incident to arrest because it was seized in the arrestee's 'reaching area."').
} 


\section{a. Phones Are Not Belton Containers}

As lower courts have stated, phones are not encompassed by Belton's definition ${ }^{179}$ of a container for Fourth Amendment purposes. ${ }^{180}$ The seminal Supreme Court rulings regarding searching containers incident to arrest "were not made with mobile phones, smartphones and handheld computers - none of which existed at the time-in mind."181 The amount of personal data one can store on an electronic device far exceeds that of a traditional container, which increases one's expectation of privacy in its contents. ${ }^{182}$ Indeed, a person would need "large suitcases, if not file cabinets" to carry the physical equivalent of a phone's stored data. ${ }^{183}$ Because phones can contain such a wealth of personal data, it is illogical to treat them in the same manner as traditional containers. The cases treating phones as traditional physical containers ${ }^{184}$ are misguided as modern cell phones are not analogous to Robinson's crumpled cigarette packet. $^{185}$

\section{b. Chimel's Justifications Are Not Applicable to Phones}

Because a phone is not a weapon and its contents are not at risk of destruction, Chimel's officer safety and destruction of evidence rationales are simply not applicable to phones. ${ }^{186}$ Whatever remote risk a phone poses to officer safety is dispelled once the phone is in the hands of the seizing officer. ${ }^{187}$ Also, a phone's data is rarely, if ever, at risk of destruction because the service provider stores this information, and the use of Faraday bags can eliminate any threat of remote tampering. ${ }^{188}$ For these reasons, Chimel cannot apply to cell phone searches incident to ar-

179. Belton, 453 U.S. at $460 \mathrm{n} .4$ (defining a container as "any object capable of holding another object").

180. E.g., State v. Smith, 920 N.E.2d 949, 954 (2009) (stating that other courts have missed Belton's implication that a "container must actually have a physical object within it").

181. People v. Diaz, 244 P.3d 501, 516-17 (2011) (Werdegar, J., dissenting).

182. Schlossberg v. Solesbee, 844 F. Supp. 2d 1165, 1170 (D. Or. 2012).

183. Id. at 1169.

184. E.g., United States v. Finley, 477 F.3d 250, 260 (5th Cir. 2007) (“[A] cell phone is analogous to a closed container.").

185. See Diaz, 244 P.3d at 513 (Werdegar, J., dissenting) ("[E]lectronic communication and data storage devices ... are not sufficiently analogous to ... the crumpled cigarette package in Robinson to justify a blanket exception to the Fourth Amendment's warrant requirement.").

186. MacLean, supra note 131, at 67-68.

187. United States v. Flores-Lopez, 670 F.3d 803, 806 (7th Cir. 2012).

188. See supra Parts III.A. 1 \& 3 (discussing how a phone's data is not realistically at risk of destruction). 
rest and a different standard must be implemented.

\section{Strengths of Treating a Phone Search Like a Home Search}

The policy goals of limiting officer discretion and augmenting individuals' privacy favor increasing the protection afforded to phones in searches incident to arrest.

\section{a. Limiting Officer Discretion}

Requiring a warrant or an exigency to search a cell phone draws a clear line for law enforcement in the field. Officers would know that, absent clearly defined exceptions, a seized cell phone may not be accessed until a warrant is secured. This is important because circumscribing officer discretion has been a touchstone of Fourth Amendment jurisprudence. ${ }^{189}$ As an Oregon district court stated, "A primary goal in search and seizure law has been to provide law enforcement with clear standards to follow." "190 To accomplish this goal "[a] single, familiar standard is essential to guide police officers, who have only limited time and expertise to reflect on and balance the social and individual interests involved in the specific circumstances they confront."191 Obviously, because officers may encounter an infinite array of unique and possibly dangerous situations, the Supreme Court prefers that officers' boundaries be clearly defined and easily applied. ${ }^{192}$ Applying this Note's proposed standard-requiring a warrant or an exigency to search a phone incident to arrest-accomplishes this goal while also protecting individuals' reasonable expectations of cell phone privacy.

b. Increasing Privacy for Individuals

A rule requiring a warrant or exigency to search a cell phone protects a person's expectation of privacy in the phone's data. This expectation

189. See, e.g., Delaware v. Prouse, 440 U.S. 648, 661 (1979) ("[T]he Court has ... insisted that the discretion of the official in the field be circumscribed ....").

190. Schlossberg v. Solesbee, 844 F. Supp. 2d 1165, 1170 (D. Or. 2012).

191. Dunaway v. New York, 442 U.S. 200, 213-14 (1979).

192. See Prouse, 440 U.S. at 661 ("[S]tandardless and unconstrained discretion is the evil the Court has discerned when in previous cases it has insisted that the discretion of the official in the field be circumscribed ....”); see also Terry v. Ohio, 392 U.S. 1, 21-22 (1968) (discussing how an objective standard to guide police officers is imperative, as anything less would "invite intrusions upon constitutionally guaranteed rights based on nothing more substantial than inarticulate hunches, a result this Court has consistently refused to sanction"). 
of privacy is "extremely high" due to the amount of personal data that a phone can store. ${ }^{193}$ This proposed standard draws a clear line to eliminate the risk that an officer may rummage through an arrestee's phone without a warrant and protects individuals from highly intrusive situations like Newhard $v$. Borders, where the police officers discovered explicit personal photos. ${ }^{194}$ While the circumstances surrounding some arrests would permit an extensive phone search, "innocent" arrestees such as traffic violators should not be subjected to a phone search. To better protect individual privacy, this judgment should be left to an unbiased magistrate rather than an officer whose duty is detecting crime.

\section{Shortcomings: Limiting Officer's Investigatory Ability and}

Burdening Law Enforcement

Treating cell phone searches like home searches would have shortcomings, including the investigatory limitations imposed on law enforcement and the added burdens involved in securing a warrant. Undoubtedly, this proposed standard swings the pendulum in favor of the individual at the expense of law enforcement and also imposes a smallbut not insignificant - burden on police officers wishing to search a cell phone.

Requiring a warrant absent exceptional circumstances limits the ability of police officers to investigate ongoing crimes, as police officers would not be able to immediately invade a phone's data to retrieve information about co-conspirators or any possible crimes committed. This is unlike the reason-to-believe standard that stresses evidence gathering at the expense of individuals' rights. ${ }^{195}$ However, evidence gathering is not a justifiable reason to search an item on one's person incident to arrest under Chimel $^{196}$ and is not a consideration under this Note's proposed solution.

This limitation on police investigation is necessary because, in light of the Supreme Court's insistence on clear standards for officers, the al-

\footnotetext{
193. See Earnes, supra note 123, at 501 (discussing the "vast amounts of highly private information" a phone can store, including the information available via "cloud computing").

194. See Newhard v. Borders, 649 F. Supp. 2d 440, 444 (W.D. Va. 2009) (searching a phone without a warrant, police officers discovered sexual photos of arrestee's girlfriend and shared them with other officers for their "viewing and enjoyment").

195. See Gershowitz, supra note 148, at 48 (discussing reason-to-believe searches as being justified by an evidence-gathering rationale).

196. See Chimel v. California, 395 U.S. 752, 763 (1969) (allowing searches incident to arrest based on officer safety and preservation of evidence justifications).
} 
ternative option-allowing suspicionless searches of the contents of every arrestee's phone - is unreasonably invasive in many cases. For instance, if given carte blanche to search all arrestees' phones, an officer could search the phone of an individual who is arrested for a simple traffic violation, exposing all sorts of stored private information. ${ }^{197}$ A search based on these facts seems to invade one's reasonable and justifiable expectation of privacy. While general crime-fighting is a worthy goal, this type of warrantless rummaging is the discretionary evil that would erode the privacy rights the Fourth Amendment was designed to protect. ${ }^{198}$ For this reason, an objective magistrate must weigh the need to invade the arrestee's privacy. ${ }^{199}$

Requiring a warrant for phone searches undoubtedly imposes a greater burden on law enforcement, but the resulting increased protection of privacy outweighs this burden. Further, while officers would not be able to immediately search the arrestee's phone, a warrant can generally be secured in the span of several hours or less. ${ }^{200}$ This lapse of time is a small price to pay so that a magistrate can weigh the need to search an arrestee's phone. Also, Judge Posner implied in Flores-Lopez that, should officers have to obtain a warrant, safeguarding the phone from remote tampering was a significant burden. ${ }^{201}$ This concern is misplaced, as countermeasures to remote tampering are easily employed ${ }^{202}$ and may be unnecessary in the first place. ${ }^{203}$ Requiring officers to acquire a warrant prior to searching a phone might impede law enforcement to a small degree, but preventing unreasonable searches and promoting individuals' reasonable privacy interests more than justify this burden.

197. Gershowitz, supra note 148 , at 28 .

198. See Delaware v. Prouse, 440 U.S. 648, 661 (1979) (labeling officer discretion in the field "evil").

199. See Schlossberg v. Solesbee, 844 F. Supp. 2d 1165, 1170 (D. Or. 2012) (discussing how, because electronic devices have a high expectation of privacy, an officer may not search their contents incident to arrest).

200. See Parker v. State, 223 S.W.3d 385, 389 (Tex. App. 2005) (discussing an officer's testimony that revealed obtaining a search warrant in this jurisdiction usually takes "a little over an hour"); State v. Brown, No. CR0284500T, 2004 WL 424257, at *9 (Conn. Super. Ct. Feb. 18, 2004) (implying that obtaining a search warrant takes an average of two hours in this jurisdiction).

201. See United States v. Flores-Lopez, 670 F.3d 803, 810 (7th Cir. 2012) (discussing the burden carrying Faraday bags would impose on police officers).

202. See supra Part III.A.3 (discussing how Faraday bags are simple and effective).

203. See supra Part III.A.1 (discussing how a phone's risk of evidence destruction is negligible). 


\section{CONCLUSION}

In Flores-Lopez, the Seventh Circuit discussed many of the issues involved in searching a phone incident to arrest, yet ultimately allowed the search based on Chimel's destruction of evidence justification. Judge Posner's opinion noted the amount of private material that is now stored on smart phones, but dismissed a workable solution in Faraday bags. By allowing the limited search based on a small risk to evidence, the Seventh Circuit perpetuated the myth that Chimel's justifications can be seamlessly applied to modern cell phones. Cell phones pose no physical risk to officers and, once the phone is seized, there is virtually no risk of data destruction. Therefore, a new method of evaluating cell phone searches incident to arrest is necessary.

The Supreme Court's reason-to-believe standard adds to the discussion but lacks doctrinal foundation in Fourth Amendment jurisprudence. The standard draws arbitrary lines and leaves open the possibility of highly invasive warrantless searches. The best method of safeguarding individuals' privacy interests and adhering to Fourth Amendment language involves a standard similar to what is required for home searches, which necessitates a warrant or circumstances justifying an exception to the warrant requirement. This standard is justifiable because phones contain large amounts of highly private material which was previously kept inside the home. Consequently, individuals have extremely high expectations of privacy in their phones' data. Requiring a warrant also draws a clear line for law enforcement officers and minimizes officer discretion as the Supreme Court has repeatedly stressed. In summary, until the Supreme Court forms a rule more adaptive to modern technology, a cell phone search incident to arrest should require a warrant or exceptional circumstances in order to best protect society's privacy interests and eliminate unconstitutional searches. 